\section{Children Australia}

www.cambridge.org/cha

\title{
Climate change action-It's a welfare responsibly too
}

Jennifer Lehmann

\section{Editorial}

Cite this article: Lehmann J (2019). Climate change action-It's a welfare responsibly too. Children Australia 44: 99-102. https://doi.org/ 10.1017/cha.2019.36
(C) The Author(s) 2019. Published by Cambridge University Press.
When Greta Thunberg stopped attending school to take up her solitary vigil outside the Swedish parliament, in protest at the failure to act on climate change, something remarkable happened. A whole generation of children and young people were inspired by her tenacity, her clarity of purpose and her message (Frischmann, 2019). Adults took notice. At the World Economic Forum and at the UN's global climate summit in Poland, Greta couldn't have been more focussed, telling world leaders that 'they are stealing [children's] future in front of their very eyes' (Winston, 2019, p. 2).

What followed were the mass protests by young people against the appalling inaction on climate change. 'Every week, thousands of Belgian youth are marching on the EU capitol of Brussels,' reported Andrew Winston (2019) for the Harvard Business Review.

[O]n March 15, in what may be the largest youth-led protest in history, an estimated 1.6 million students in 300 cities around the world walked out of school to march for climate action. I went to the New York march and the energy was electric - and I didn't even take it personally when a group of teens called some colleagues and me 'old people' who need to do something.

But why have we 'old people' failed collectively to act? To be sure, there are those among us who have been fiercely campaigning for climate action for years. And yet here we are, still putting the power of government in the hands of individuals who seem unable to recognise the connections between community welfare and the welfare of the natural systems that support us.

Over the last two decades, as the consequences of climate change have become increasingly apparent and experienced directly by growing numbers of people, it has also become ever clearer that climate change will significantly affect the well-being of the current generation of children and young people. No wonder, then, that in Portland, Oregon, a lawsuit has been lodged by 21 young people on the grounds that 'US energy policies are causing climate change and hurting their future' (Selsky, 2019). While both the Obama and Trump administrations have sought to have the lawsuit dismissed in the years since it was lodged in 2015 , the judges, as I write this, are yet to make a decision. How much longer companies, governments or individuals can shun responsibility for actions or policies that promote emissions is an interesting question. We have known for more than 50 years that fossil fuels and their concomitant carbon emissions affect the world's climate. In fact, my adult daughter remembers being taught about climate change and sea level rise back in the early 1990s - so at least three generations have been made aware of the dangers .... and counting.

Our failure to act is now putting everyone at the risk of the most serious impacts of climate change, including water and food scarcity, extremes of heat and cold, the spread of disease and injury related to extreme weather events. However, as World Vision Australia (2019, p. 1) points out, the future for children is particularly disturbing because they 'are at greatest risk of injury, disability and death caused by the impacts of climate change.' As World Vision Australia notes, children, when their bodies are still growing, are:

less equipped physically, mentally and emotionally to cope with life-threatening conditions. The greatest killers of children - malnutrition, diarrhoeal disease and malaria - will get worse because of climate change. Children living in developing countries face the greatest risks of all, not because climate change effects will be any worse there than in other countries, but because poverty limits their ability to respond.

While the children and young people on strike in westernised nations like Australia have been largely spared the impacts of climate action on their growth and development, the bitter reality is that during their lifetimes, they will see growing numbers of children directly and indirectly affected by climbing temperatures. It is not the case, as some academics have suggested (Rousel \& Cutter-Mackenzie-Knowles, 2019) that today's young people 'are the first generation to have lived their entire lives under the threat of catastrophic climate change' (my italics). Rather, they are the first generation who, as adults, are locked into living in a climate-altered world thanks to decades of inaction. What remains open to us - and to them - is the power to change how much the climate alters from here on in. Like the students' placards read, 'there is no Planet B' if we continue to stuff around.

Here, in Australia, the school strikes of early 2019 were accompanied by a renewed sense of optimism that overdue political action was just around the corner (Feldman, 2019). Much attention and praise was given to the leadership demonstrated by the students, both by their adult supporters and the media - and so the students are leading, and so they must. 
However, in observing the energy generated by the strikes, followed in short order by the re-election of a conservative government by adult voters, we are reminded that it is not the responsibility of youth to do 'the heavily lifting' of making change happen. For adults, the cultural mindset that tacitly shifts responsibility for change to the young, while conveniently neglecting the centrality of adults' power and authority, is a constant danger that creates a vacuum of inaction. After all, today's adults are yesterday's generation of youngsters who, not so long ago, were being told that they were 'tomorrow's leaders' and the community's hope for the future. Which begs the question: at what point in our adulthood do we become less responsible for change than the younger generation coming behind us?

Clearly, the preparations for lifestyle, logistics and systems change should have started long ago, and it is an indictment that climate inaction and low trust in politicians now rate as chief issues of concern for young people (UNICEF Australia, 2019). UNICEF Australia reports that:

[C]hildren and young people in Australia today are overwhelmingly worried about the threat of climate change and the ongoing failure and seeming unwillingness of successive governments to take any effective action to mitigate what they consider to be a formidable threat. ... It is overwhelmingly clear their views are informed by engagement with the science and a rejection of ideology. (2019, p. 14)

More disturbingly, while we may grasp that young people are worried about their future - and even concur that they have reason to be so - what we are also beginning to witness is the emergence more widely of what Tim Winton (2019) describes as a 'bruised attitude of beleaguerment in individuals and in groups', the result of "[b] usiness as usual ... white-anting the promise of change." Winton, one of the Australia's most celebrated authors and astute social observers, described this emerging sense of woundedness in a powerful commentary article published by The Guardian in April 2019. Throughout neighbourhoods and towns, ecological depletion, he writes, is now:

being experienced communally as a mounting loss of access and an erosion of possibility. In essence, a pruning back of future prospects. It's expressed as grief, and the most palpable, widespread and immediate expression of it is now brewing over climate change. Beneath that grief there's rage. (Winton, 2019)

Grief, rage and hopelessness take a huge toll on people's well-being, even when they are experienced or expressed existentially rather than as personal reactions to individual circumstances. We may be more comfortable with the medicalised model of mental health, but, as Fritze, Blashki, Burke and Wiseman (2008) indicate, we need to recognise that mental health is determined by social, economic and environmental factors. In doing so, we also need to understand 'that the full extent of the long-term social and environmental challenges posed by climate change has the potential to create emotional distress and anxiety' (n.p.).

The paper by Fritze et al. is now over a decade old and chiefly concerned with the short- and long-term impacts of climate change on mental health, which may arise from the displacement of individuals and communities following disasters, economic restructuring related to climate change and energy and the fracturing of relationships associated with family, work and community. However, their paper remains highly pertinent because it recognises that 'In the long-term, hope and morale in the community about climate change are deeply intertwined with mental health promotion.' As the authors suggest, if pessimism and despair are allowed to take hold, this will have profound consequences for individual and collective meaning and purpose. We need instead to view our environmental challenges as an opportunity to 'galvanise creative ideas and actions in ways that transform and strengthen the resilience and creativity of individuals and communities' (Fritze et al., n.p.).

As human services professionals, we are supposed to be experts when it comes to understanding trauma, distress, despair and anger. We are also supposed to be concerned for the welfare of families and to protect children from harm. This is a moment when we need to bring all our knowledge and skills to bear to support the individual and collective actions needed to limit climate change and respond to its effects. I don't often feel drawn to the metaphors of war, but perhaps this is the time to be militant, to loudly articulate our role in protecting children - today's children, and the children to come - and to take a stronger stance against the policies and practices that are slowly "white-anting" the optimism of communities.

All this is easy to say, of course, but what might it mean in practice? For a start, it's not easy to build climate action into case work when there are other issues being experienced by young people that appear more urgent. However, as social workers - as persons perceived to be of authority (bureaucratic or otherwise) in the lives of our clients - we do have the opportunity to model useful, climate-aware behaviours and approaches that simultaneously assist young people in developing the skills and attitudes needed to bolster their resilience in the long run.

Firstly, let's reflect on our own values and attitudes. We need to consider how our ideas and lifestyle expectations contribute to emissions and the degradation of natural systems. Social workers, by and large, identify as middle-class professionals. But, what kind of 'middle class' are we exactly? Are we the middle-income 'aspirational' types, people who are 'mainly concerned with material improvement or gain' (which is how the term 'aspirational voter' is defined by the Australian National Dictionary (Moore, Laugesen, Gwynn, \& Robinson, 2016))? If we are, then there's an immediate problem because it's that very preoccupation with accumulation - with money and conspicuous consumption - that is the major driver of emissions and pollution and encourages us to put a lot of simple lifestyle changes in the too-hard basket.

Alternatively, might we not be the sort of 'middle class' that could be termed inquisitive rather than acquisitive: curious to engage with people, to find ways to break out of conventional consumerism, and to bend money towards what minimises the necessity to constantly accumulate? This, surely, represents a much smarter, more considered set of class values for any era - and particularly in one when the endless manufacture and consumption of 'stuff are proving to be so destructive. It is certainly a healthier model to set before the children and young people we work with, many of whom will be better served by developing the skills for low-impact living and social connectedness for resource sharing.

So how might we model this approach? In the first instance, we can do so through our agencies and staff practices. We can promote and normalise the use of public transport, for example, by ensuring our agencies are pedestrian and bike-friendly and that staff are aware and encouraging of public transport options (and accommodating when clients are sometimes delayed by transport glitches). Directors and senior managers can put greater emphasis on venue features and facilities that are durable rather than following office design fashion trends - which includes resisting frivolous branding and advertising exercises that result in the waste of materials. Workloads ought to be proactively structured to ensure that people 
actually have time to walk short distances for meetings instead of relying on cars, and more organisations might consider taking up the challenge of going carbon-neutral, not for the sake of sustainability per se, but as a statement of concern for the welfare of children and families into the future.

More importantly, we can model climate action directly in our work with carers, children, families and young people. In our conversations, we can give high regard to activities that are of both individual and community benefit and that use less energy or create less waste. We can validate carers and parents who let children walk or ride to school and encourage the giving of presents that are lasting, handmade, or help young people to develop their skills to mend, make or make-do. We can teach children to minimise the use of heating and cooling appliances by encouraging them to dress appropriately for the weather - and speaking of appropriate clothing, we can support families to equip children with good walking shoes so that they can comfortably get from $\mathrm{A}$ to $\mathrm{B}$ on foot. We can make a point of reminding ourselves or children to turn off screens, lights or other appliances when we have finished in a room space, not because the flick of a switch will save the planet, but because the critical issue is where the emphasis falls in the conversations. For example, do you talk about plane travel as something warranting special consideration (because it entails huge carbon emissions) or as an everyday option that anyone can automatically use? When children are present, do you respond to advertising as a nuisance to be regarded critically, or as legitimate messaging about what everybody ought to have? When families are present, do you show leadership by stopping to pick up rubbish, or do you ignore it and give the message that it's (hopefully) someone else's problem?

Increasingly, there are also opportunities to connect families and young people with community organisations that are committed in various ways to 'reducing', 'reusing' and 'recycling' - think public libraries, repair cafes (where volunteers not only fix items but also show how it's done), community gardens, men's sheds (which, like repair cafes, often have members who can help with mending items) and neighbourhood houses. Joining these groups or accessing their members' skills can be more empowering for families and individuals than you first expect because they demonstrate not only how skills and solutions can be shared but also give families a broader sense of who and what is available around them. If we are serious about helping families and individuals to build their confidence and resourcefulness, we might also consider taking children and young people on outings more frequently to places that illuminate how systems work like quarries, reservoirs and water treatment plants, landfills, orchards or plantations, and factories (including chocolate factories!). Such sites teach young people to grasp scale and human impact. Significantly, they also show humanity's power to organise and transform: the potential to create change that is negative or positive.

Fundamentally, we need to discourage young people from thinking that all aspects of the current middle-class lifestyle are worth aspiring to. Many of the people we work with already find it difficult, perhaps impossible, to get traditional, steady jobs, and while there will always be employment in sectors like health and education, the jobs of the future may exist in very different forms. Whether or not young people have the experience of 'normal' employment, they need to be able to live lightly, create, grow and mend, share resources, and be able to gain satisfaction and enjoyment free from the pressures of consumerism and ideologies that equate glitzy materialism with success. Importantly, we need to be seen to do the same. Action to halt climate change will not necessarily mitigate in obvious ways the situation of disadvantage into which a child is born. But, limiting global warming is crucial if we want to prevent young people's experiences of disadvantage becoming substantially worse. Let's draw energy from the fact that many actions which can be taken to reduce emissions also serve to promote social connectedness, healthy communities and resourcefulness, and confidence in everyone's ability to initiate, advocate for and sustain change.

Moving on to the content of this issue of Children Australia, we have for you an interesting mix of practice commentaries and articles that explore a range of topics. We begin with a practice commentary by Margaret Rogers who considers the ways in which narratives are used as a cultural tool to share knowledge and ideas and the sometimes persuasive power this can have over an individual's life choices. Margaret uses the somewhat contentious topic of childhood immunisations as a vehicle for examining the nature of cultural narratives and the ways in which these can be harnessed for disseminating public health messages.

Angelika Poulsen looks at the nature of corporal punishment in contemporary Australia. While this punitive response by parents and guardians is legal (within certain parameters), the literature suggests that it can negatively impact on children's mental and physical well-being and can create long-lasting impressions that carry on into adulthood. Poulsen talks about the nature of the data and literature on corporal punishment and makes suggestions for further research to help gain a better understanding of its prevalence, impact and actions to discourage its use.

At the more extreme end of the violence continuum is a paper authored by Peter Mertin who examined domestic homicide. Peter's review of literature on domestic homicide focusses on the nature of children's care after the death of their mother and the loss of their father to prison or suicide. Peter considers the impact that the incident and subsequent loss of home, neighbourhood and school can have on children. This review revealed a lack of reference or recommendation for those determining the best course of therapeutic action and place for care/residence for children who lost their parents as a result of domestic homicide.

An interesting evaluation of the Journey to the Island of Calm program undertaken by Hyacinth Udah, Jennifer Cartmel, Gil San, and Amanda Prause found that children aged between 9 and 12 years who participated in this program experienced improved self-regulation and self-understanding, which ultimately aids in their social and emotional development and well-being.

Also within a school setting, David Mander and Leanne Lester used a mixed-methods approach to investigate the preparedness and overall well-being of boys transitioning from primary school to a secondary boarding school. They found participants to have a mixture of apprehension along with a sense of positivity about the educational opportunities that awaited them. Reports of psychological distress were low, but so too was academic selfperception.

This edition of Children Australia ends with two papers examining issues to do with child protection and out-of-home care. Ines Zuckowski spoke with child protection practitioners in Northern Queensland about their experiences of working in the child protection system 5 years after the release of the Carmody Inquiry. Participants spoke of the increased complexity of cases, issues to do with legislation and policy, and the application of traumainformed practice. They highlighted the connection between child protection and domestic violence, with families continuing to endure violence because of Family Law Court orders and inadequate support. Finally, a paper presented by Margarita Frederico, Allison Cox and Hameed Mohajer describes the development of the Take 
Two Stakeholder Survey, as well as some detail about service users' experiences of the therapeutic programme.

\section{References}

Feldman, H. (2019, May 2). Young people won't accept inaction on climate change, and they'll be voting in droves. The Conversation. Retrieved from http://theconversation.com/young-people-wont-accept-inaction-on-clim ate-change-and-theyll-be-voting-in-droves-116361

Frischmann, C. (2019, March 29). The young minds solving climate change. Retrieved from the British Broadcasting Corporation website: http://www. bbc.com/future/story/20190327-the-young-minds-solving-climate-change

Fritze, J., Blashki, G., Burke, S., \& Wiseman, J. (2008). Hope, despair and transformation: Climate change and the promotion of mental health and wellbeing. International Journal of Mental Health Systems, 2, 13. doi:10.1186/1752-4458-2-13

Moore, B., Laugesen, A., Gwynn, M., \& Robinson, J. (Eds.) (2016). The Australian national dictionary: Australian words and their origins. South Melbourne, Victoria: Oxford University Press.

Rousel, D., \& Cutter-Mackenzie-Knowles, A. (2019). Climate change: Young people striking from school see it for the life-threatening issue it is. The Conversation. Retrieved from https://theconversation.com/climate-change- young-people-striking-from-school-see-it-for-the-life-threatening-issue-itis- 111159

Selsky, A. (2019, June 4). Young people suing U.S. government over climate change get their day in court. PBS News Hour. Retrieved from https:// www.pbs.org/newshour/nation/young-people-suing-u-s-government-overclimate-change-get-their-day-in-court

UNICEF Australia. (2019). Climate change inaction, low trust in politicians, addressing mental health - Report reveals the issues concerning Australia's young people. Retrieved from https://www.unicef.org.au/about-us/media/ april-2019/climate-change-inaction-low-trust-in-politicians

Winston, A. (2019, March 26). Young people are leading the way on climate change, and companies need to pay attention. Harvard Business Review. Retrieved from https://hbr.org/2019/03/young-people-are-leading-theway-on-climate-change-and-companies-need-to-pay-attention

Winton, T. (2019, April 20). Our leaders are ignoring global warming to the point of criminal negligence. It's unforgivable. The Guardian. Retrieved from https:/www.theguardian.com/environment/2019/apr/20/ our-leaders-are-ignoring-global-warming-to-the-point-of-criminalnegligence-its-unforgivable

World Vision Australia. (2019). Climate change: The effects on children. Retrieved from https://www.worldvision.com.au/global-issues/work-wedo/climate-change/climate-change-the-effects-on-children 